Check for updates

Cite this: Chem. Sci., 2019, 10, 9542

๑ All publication charges for this article have been paid for by the Royal Society of Chemistry

Received 14th June 2019

Accepted 19th August 2019

DOI: $10.1039 / c 9 s c 02923 k$

rsc.li/chemical-science

\section{Ion-pair induced supramolecular assembly formation for selective extraction and sensing of potassium sulfate $\uparrow$}

\author{
Damian Jagleniec, Łukasz Dobrzycki, (D) Marcin Karbarz (D) and Jan Romański (D)*
}

\section{Introduction}

Due to the numerous roles played by sulfates in the environment and biological systems, the design of artificial receptors able to selectively recognize sulfates is of great interest in supramolecular chemistry. ${ }^{1}$ Sulfates have a very high hydration energy $\left(-1090 \mathrm{~kJ} \mathrm{~mol}^{-1}\right),{ }^{2}$ making strong and selective binding of this anion by neutral receptors a very challenging task, especially under aqueous or interfacial conditions. On the other hand, selective binding of extremely hydrophilic sulfate anions over lipophilic anions, such as nitrate anions (hydration energy $\left.-306 \mathrm{~kJ} \mathrm{~mol}^{-1}\right),{ }^{2}$ is highly desired and requires the Hofmeister bias to be overcome. ${ }^{3}$ One field of potential application is environment protection, for instance in the disposal of sulfateand nitrate-containing high-level liquid waste (HLLW) stored at the Hanford site. ${ }^{4}$ The presence of sulfates in HLLW and their low solubility limit in borosilicate glass is a serious issue and is problematic upon vitrification of HLLW. Sulfates cause corrosion of glass melters and the constituent electrodes and are responsible for the decrease of durability of glass logs, directly

Faculty of Chemistry, University of Warsaw, Pasteura 1, PL 02-093 Warsaw, Poland. E-mail: jarom@chem.uw.edu.pl

$\dagger$ Electronic supplementary information (ESI) available: General information, synthetic details, ${ }^{1} \mathrm{H}-\mathrm{NMR}$ and UV-vis titration data, extraction experimental details, X-ray crystal data for $1 \times \mathrm{Na}_{2} \mathrm{SO}_{4}$ (CCDC 1877168), $1 \times \mathrm{KNO}_{3}$ (CCDC 1877169) and $1 \times \mathrm{H}_{2} \mathrm{O}$ (CCDC 1877170). CCDC 1877168-1877170. For ESI and crystallographic data in CIF or other electronic format see DOI: $10.1039 / \mathrm{c} 9 \mathrm{sc} 02923 \mathrm{k}$ posing a safety hazard during vitrification and storage. One of the ways of sequestering sulfates from their aqueous solutions involves anion or ion pair receptor facilitated liquid-liquid extraction (LLE). In this context it has been demonstrated that properly preorganized macrocyclic, tripodal or charged anion receptors can be used as sulfate extractants. ${ }^{5}$ However, in such cases a bulky counterion needs to be present and the process has the nature of an exchange rather than extraction. To the best of our knowledge, simple extraction of sulfates associated with alkali metals from the aqueous to the organic phase has not yet been reported in the literature. We envisioned that utilizing the advantage of ion pair receptors, as compounds which can bind ion pairs cooperatively and are able to interact with salts under interfacial conditions, may fill this gap in methodology. ${ }^{6}$ Nature solved the problem of sulfate binding by means of the sulfate binding protein (SBP), where four sulfate oxygen atoms are bound through seven hydrogen bonding interactions donated by specific residues of the protein. ${ }^{7}$ Thus we addressed the question of whether several relatively simple and rigid non-multimacrocyclic ion pair receptors can form hydrogen bonding inorganic-organic core-shell like assemblies and enable selective extraction of sulfates from the aqueous to the organic phase. The basis for distinguishing nitrate and sulfate anions should be the formation of complexes of various stoichiometry depending on the valency and geometry of the anions tested, which should affect the solubility of the complexes in the organic phase. To verify our hypothesis we designed and synthesized squaramide based ion pair receptors 
in which the anion binding site is directly linked with an electron deficient phenyl ring and with a benzo 18-crown-6 unit (Scheme 1).

\section{Results and discussion}

The synthesis of receptors $\mathbf{1}$ and $\mathbf{2}$ is outlined in Scheme 2 . Briefly, receptor 1 was obtained by sequential amidation of dimethyl squarate with 3,5-trifluoromethylaniline followed by 4aminobenzo-18-crown-6. In the case of receptor 2 , which is designed as a simple optical sensor, 4-nitroaniline was used in the first step of synthesis. All intermediates and receptors can be simply purified by crystallization and are thus easily accessible on a large scale.

Initial evidence that squaramide $\mathbf{1}$ might act as an ion pair receptor and is able to interact with anions in the presence of cations in an enhanced manner came from UV-vis spectroscopy in acetonitrile. The addition of incremental amounts of TBA salts of various anions to a solution of 1 caused bathochromic shifts in the absorption maximum of the receptor, enabling the determination of apparent stability constants. We found that receptor 1 binds these anions with moderate to very high strength, in the order $\mathrm{I}^{-}<\mathrm{NO}_{3}{ }^{-}<\mathrm{Br}^{-}<\mathrm{NO}_{2}{ }^{-}<\mathrm{Cl}^{-}$(Table 1). Due to the very strong interaction of receptor 1 with chlorides

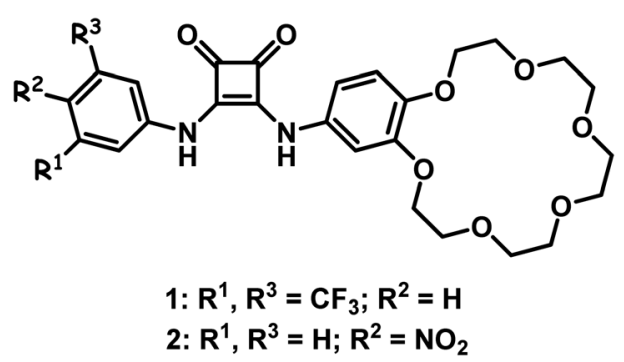

Scheme 1 Squaramide-based receptor 1 and sensor 2.

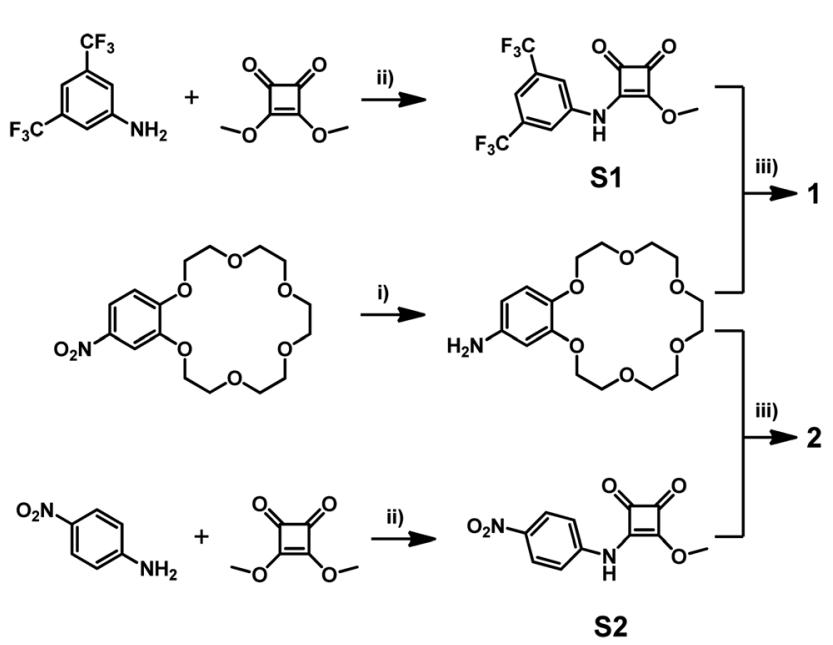

Scheme 2 Synthesis of receptors 1 and 2. Reagents and conditions: (i) $\mathrm{H}_{2}, \mathrm{Pd} / \mathrm{C}, \mathrm{MeOH}-\mathrm{THF}, 12 \mathrm{~h}$, r.t., and quantitative; (ii) methanol, $72 \mathrm{~h}$, r.t., $95 \%$ for $\mathrm{S} 1$ and $84 \%$ for S2; (iii) methanol, 48 h, r.t., $90 \%$ for 1 and $75 \%$ for 2 . and the variability of data due to water capture during titrations, we were able to obtain reliable stability constants when we standardized conditions and carried out experiments in the presence of $0.5 \%$ water. In the case of a basic anion, such as acetate, dihydrogen phosphate or hydrogen phosphate deprotonation was observed. Interestingly, when receptor 1 was titrated in the presence of one equivalent of sodium or potassium cations (added as $\mathrm{NaClO}_{4}$ or $\mathrm{KPF}_{6}$ ), an enhancement in anion binding was observed in all cases. This can be attributed to an increased acidity of squaramide protons upon interaction of the benzocrown unit with cations, which reinforce interactions with anions. ${ }^{8}$

As expected, for receptor 1 possessing a benzo-18-crown-6 unit, the highest enhancement in anion binding was observed for titrations performed in the presence of potassium rather than sodium cations. This correlates well with the association constants obtained for complexes of receptor $\mathbf{1}$ with sodium (added as $\left.\mathrm{NaClO}_{4}\right)$ and potassium (added as $\left.\mathrm{KPF}_{6}\right)$ cations $\left(K_{\mathrm{Na}^{+}}\right.$ $=48700 \mathrm{M}^{-1}$ and $K_{\mathrm{K}^{+}}=133300 \mathrm{M}^{-1}$ ). This is also supported with titrations performed in the presence of $5 \%$ water in acetonitrile using $\mathrm{NaCl}$ and $\mathrm{KCl}$ instead of salts generated in situ. We found that in the presence of water, receptor $\mathbf{1}$ is still able to recognize these salts with stability constants of 2300 and $4300 \mathrm{M}^{-1}$ for $\mathrm{NaCl}$ and $\mathrm{KCl}$, respectively.

Strikingly, when a divalent sulfate anion was tested as a tetrabutylammonium salt in acetonitrile the $2: 1$ binding mode was better suited while the $1: 1$ fitting produced a high error rate. Furthermore, an analogous titration experiment conducted in the presence of potassium cations produced an isotherm with a two-step binding profile, indicating the occurrence of a more complex binding equilibrium depending on the concentration of in situ generated $\mathrm{K}_{2} \mathrm{SO}_{4} \cdot{ }^{9}$ This also demonstrates the differing ability of free receptor $\mathbf{1}$ and its complex with potassium cations to recognize anions. To gain more insight into the ion pair binding mechanism and prove

Table 1 Association constants $\left(K_{\mathrm{a}}\right)$ for interactions between receptor 1 and selected anions and apparent association constants for interaction of 1 with anions in the presence of one equivalent of sodium perchlorate or potassium hexafluorophosphate ${ }^{a}$

\begin{tabular}{|c|c|c|c|}
\hline & 1 & $\begin{array}{l}\mathbf{1}+1 \\
\text { equiv. } \mathrm{Na}^{+}\end{array}$ & $\begin{array}{l}\mathbf{1}+1 \\
\text { equiv. } \mathrm{K}^{+}\end{array}$ \\
\hline $\mathrm{Cl}^{-}$ & $176000^{b}$ & $492500^{b}$ & $766000^{b}$ \\
\hline $\mathrm{NO}_{2}{ }^{-}$ & 100900 & 363200 & 509600 \\
\hline $\mathrm{Br}^{-}$ & 49800 & 142000 & 217000 \\
\hline $\mathrm{NO}_{3}{ }^{-}$ & 2500 & 5900 & 7100 \\
\hline $\mathrm{I}^{-}$ & 1940 & 3850 & 4500 \\
\hline \multirow{2}{*}{$\mathrm{HSO}_{4}{ }^{-}$} & $\mathrm{K}_{11}=15000$ & & \\
\hline & $\mathrm{K}_{21}=108900$ & $-^{c}$ & $-^{c}$ \\
\hline \multirow[t]{2}{*}{$\mathrm{SO}_{4}{ }^{2-}$} & $\mathrm{K}_{11}=58600$ & & \\
\hline & $\mathrm{K}_{21}=63300$ & $-^{c}$ & $-^{c}$ \\
\hline
\end{tabular}


disparity in monovalent and divalent anions, in particular in nitrate and sulfate binding by receptor $1,{ }^{1} \mathrm{H}$ NMR experiments were conducted in $\mathrm{CD}_{3} \mathrm{CN}$. The analysis of the binding isotherms thus obtained supported the data collected from UVvis titrations. Specifically, the data collected from nitrate titration in the absence and presence of potassium cation can be simply fitted to the $1: 1$ binding mode, suggesting the formation of a $\left[1 \times \mathrm{KNO}_{3}\right]$ complex. On the other hand, titrations carried out with both $\mathrm{TBA}_{2} \mathrm{SO}_{4}$ or in situ generated $\mathrm{K}_{2} \mathrm{SO}_{4}$ resulted in inconsistent perturbation in the titration profile. In particular, upon incremental addition of sulfate anions into an acetonitrile solution of receptor 1 containing one equivalent of potassium cations, the signals corresponding to the aromatic and crown ether protons shifted inconsistently. These signals initially shifted downfield, but after exceeding approx. 0.25 equivalents of sulfate anions they moved upfield, suggesting that in equilibrium a $4: 1$ complex (receptor : anion) is present (Fig. 1). ${ }^{10}$

Further confirmation that an inorganic/organic assembly is formed in solution, after addition of $\mathrm{SO}_{4}{ }^{2-}$ and $\mathrm{K}^{+}$to the solution of $\mathbf{1}$ in acetonitrile, came from DOSY-NMR and dynamic light scattering (DLS) studies. In order to prove the formation of a large complex, diffusion NMR experiments were carried out in $\mathrm{CD}_{3} \mathrm{CN}$. The formation of such an assembly should cause a significant decrease in the diffusion coefficient $(D)$ values. The collected data clearly indicate the formation of supramolecular structures when $\mathrm{TBA}_{2} \mathrm{SO}_{4}$ and $\mathrm{KPF}_{6}$ were added to a solution of receptor $1\left(c=3.04 \times 10^{-3} \mathrm{M}\right)$ in $\mathrm{CD}_{3} \mathrm{CN}$. The presence of in situ generated $\mathrm{K}_{2} \mathrm{SO}_{4}$ promoted a significant decrease in the diffusion coefficient of the ligand from $D=10.53 \times 10^{-10}$ to $7.56 \times$ $10^{-10} \mathrm{~m}^{2} \mathrm{~s}^{-1}$, with $\Delta D=-28 \%$. On the other hand, the addition of TBAPF $_{6}$ to the solution of $\mathbf{1}$ did not affect its diffusion coefficient. Furthermore, DLS measurements were performed to determine the size of the supramolecular assembly in $\mathrm{CH}_{3} \mathrm{CN}$. In the case of the addition of $\mathrm{TBA}_{2} \mathrm{SO}_{4}$ and $\mathrm{KPF}_{6}$ to the solution of 1 , the $Z$-average provided confirmation for the formation of a large supramolecular assembly. The value of the hydrodynamic diameter was found to be $d_{\mathrm{H}}=28 \mathrm{~nm}$ while receptor 1 alone was not detectable. Similarly, receptor 1 pretreated with in situ generated $\mathrm{KNO}_{3}$ was also not detectable by DLS, suggesting that $\mathrm{KNO}_{3}$ does not promote the formation of a large assembly in solution.

Final evidence of the formation of $4: 1$ and $1: 1$ complexes for sulfate and nitrate promoted assemblies came from X-ray
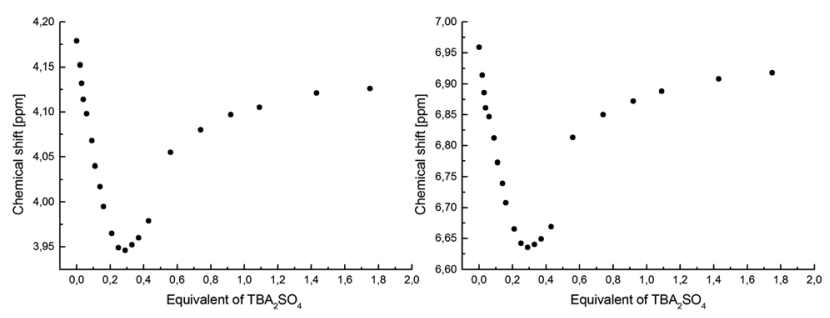

Fig. 1 Titration curves obtained by following crown ether and aromatic protons upon incremental addition of in situ generated $\mathrm{K}_{2} \mathrm{SO}_{4}$ into solution of 1 in $\mathrm{CD}_{3} \mathrm{CN}$. analysis. ${ }^{11}$ Despite making a number of attempts to crystallize complexes of receptor 1 with $\mathrm{K}_{2} \mathrm{SO}_{4}$, we were unable to obtain crystals. However, slow diffusion of diethyl ether into an $\mathrm{MeCN} /$ $\mathrm{MeOH}$ solution of 1 pretreated with an excess of $\mathrm{Na}_{2} \mathrm{SO}_{4}$ enabled us to obtain crystals suitable for X-ray diffraction analysis. The resulting structure revealed the formation of a complex with 4:1 stoichiometry, entirely embedding the sulfate into a shell formed by four ligands (Fig. 2a). The sulfate anion is surrounded by disordered receptor moieties oriented so as to form eight hydrogen bonds between the oxygen atoms of the tetrahedron-shaped sulfate and the amide hydrogen atoms. The electroneutrality of the $\left[1 \times \mathrm{Na}_{2} \mathrm{SO}_{4}\right]$ complex is ensured by two sodium cations trapped in benzocrown cavities by two out of four ligands. A different single-crystal structure was formed after slow diffusion of diethyl ether into an MeCN/ $\mathrm{MeOH}$ solution of $\mathbf{1}$ obtained after solid-liquid extraction with $\mathrm{KNO}_{3}$. In the $\left[1 \times \mathrm{KNO}_{3}\right]$ crystal structure the asymmetric part of the unit cell consists of two ligands and two $\mathrm{KNO}_{3}$ ion pairs. Like in the case of the previous structure, the potassium cations reside in the benzocrown cavities and are in addition coordinated from both sides by nitrate anions, giving an infinite 1-D polymeric assembly (Fig. 2b). Strong hydrogen bond interactions between squaramide protons and $\mathrm{NO}_{3}{ }^{-}$anions result in the formation of supramolecular layers of moieties. Interestingly, in a salt-free environment, ligand $\mathbf{1}$ crystallizes as a monohydrate $\left[1 \times \mathrm{H}_{2} \mathrm{O}\right]$ with water molecules located in the benzocrown part and additionally coordinated by $\mathrm{H}$ atoms of the squaramide moiety, giving an altogether dimeric arrangement (Fig. 2c).

Taking into consideration the different properties of nitrate and sulfate complexes with $\mathbf{1}$ formed in solution and in the solid state, we envisioned that using a squaramide-based ion pair receptor would be able to differentiate between these salts under interfacial conditions and preferentially extract sulfates into an organic phase. As a first test, LLE experiments were conducted under ${ }^{1} \mathrm{H}$ NMR control using a $2 \mathrm{mM}$ solution of $\mathbf{1}$ in $\mathrm{CDCl}_{3}$ and various aqueous $50 \mathrm{mM}$ salt solutions $\left(\mathrm{KCl}, \mathrm{KBr}, \mathrm{KNO}_{3}, \mathrm{KNO}_{2}\right.$, $\mathrm{Na}_{2} \mathrm{SO}_{4}, \mathrm{KH}_{2} \mathrm{PO}_{4}$ and $\left.\mathrm{K}_{2} \mathrm{SO}_{4}\right)$. With the exception of $\mathrm{K}_{2} \mathrm{SO}_{4}$ extraction, in all cases the precipitation of solids was noted, showing the insolubility of the supramolecular species formed in $\mathrm{CDCl}_{3}$. This opens up a unique opportunity to distinguish these salts under interfacial conditions by preferentially increasing the solubility of sulfate complexes with receptor 1 rather than complexes of 1 with other salts. Indeed, the comparison of the ${ }^{1} \mathrm{H}$ NMR spectrum of free 1 in water saturated $\mathrm{CDCl}_{3}$ revealed substantial changes in the resonance signals after contact with an aqueous solution of $\mathrm{K}_{2} \mathrm{SO}_{4}$ (Fig. $3 \mathrm{~b}$ ).

This clearly indicates that receptor $\mathbf{1}$ is able to extract extremely hydrophilic sulfate anions from the aqueous to the organic phase and form complexes in the organic layer. ${ }^{12}$ This is also supported by electron spray ionization mass spectrometric measurements of the extracted organic solution, which clearly shows characteristic peaks $(\mathrm{m} / \mathrm{z})$ appearing at $2750.7[4 \times 1+$ $\left.\mathrm{K}_{2} \mathrm{SO}_{4}+\mathrm{K}^{+}\right]$and $1316.3\left[4 \times 1+\mathrm{SO}_{4}{ }^{2-}\right]$ (see the ESI $\dagger$ ). Control experiments with an analogous urea based ion pair receptor or squaramide based ion pair receptor equipped with a benzo-15crown-5 ether or anion receptor lacking a crown ether unit 


\section{a) Structure of $\left[1 \times \mathrm{Na}_{2} \mathrm{SO}_{4}\right]$}

Disorder in the crystal structure

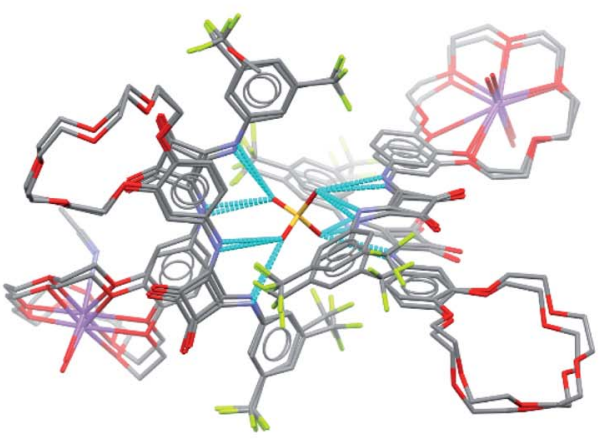

b) Structure of $\left[1 \times \mathrm{KNO}_{3}\right]$

Coordination of $\mathrm{K}^{+}$ions in the crystals

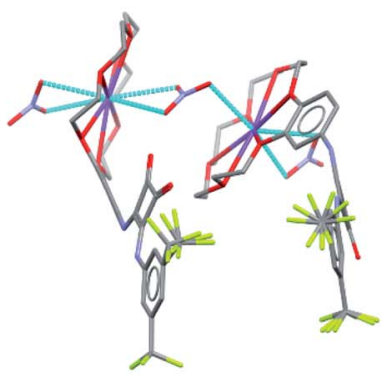

Ordered model of the structure

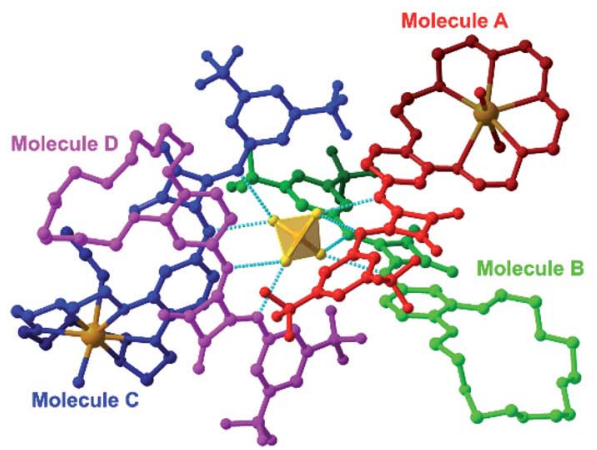

Schematic model of the supramolecular complex of $\left[1 \times \mathrm{Na}_{2} \mathrm{SO}_{4}\right]$

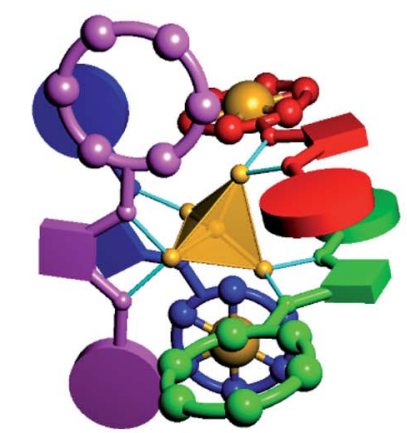

c) Structure of $\left[1 \times \mathrm{H}_{2} \mathrm{O}\right]$

Formation of 1-D K.... $\mathrm{NO}_{3}^{-}$polymers

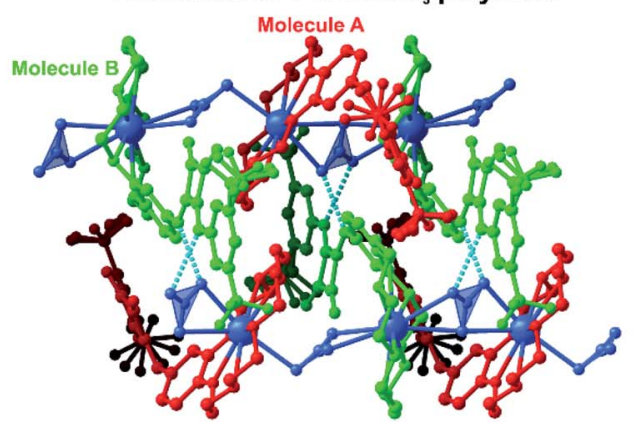

Dimers in the crystals

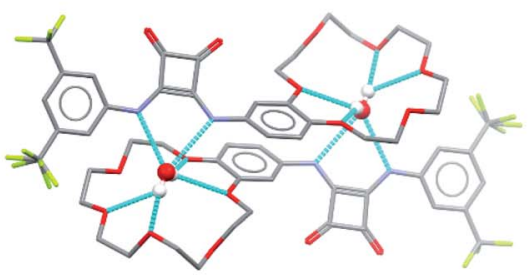

Fig. 2 Molecular assemblies in the single crystal structures of (a) $\left[1 \times \mathrm{Na}_{2} \mathrm{SO}_{4}\right]$, (b) $\left[1 \times \mathrm{KNO}_{3}\right]$ and (c) $\left[1 \times \mathrm{H}_{2} \mathrm{O}\right]$.

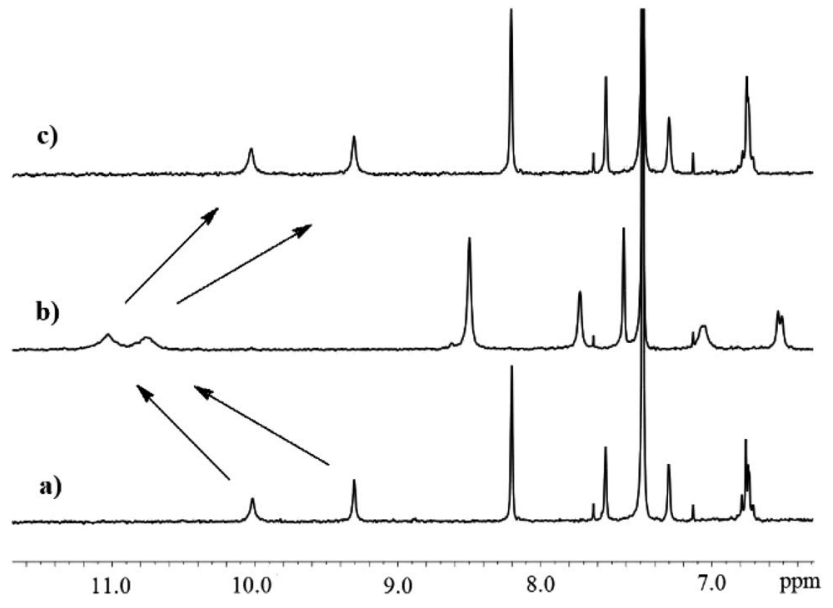

Fig. 3 Partial ${ }^{1} \mathrm{HNMR}$ spectra of receptor 1: (a) $2.0 \mathrm{mM}$ in wet $\mathrm{CDCl}_{3}$, (b) after extraction of $50 \mathrm{mM} \mathrm{K}_{2} \mathrm{SO}_{4}$ and (c) after back extraction to distilled water.

revealed an inability to extract either $\mathrm{K}_{2} \mathrm{SO}_{4}$ or $\mathrm{Na}_{2} \mathrm{SO}_{4}$ under such conditions (the receptors denoted in the ESI as $\mathrm{S} 4, \mathrm{~S} 5$ and $\mathrm{S} 3, \uparrow$ respectively). Furthermore, the ability to release potassium sulfate by receptor 1 was confirmed by a ${ }^{1} \mathrm{H}$ NMR back extraction experiment, which resulted in the signals returning to the initial position after contacting with water (Fig. 3c).
In order to establish the extraction efficiency in the experiments described above, we used atomic emission spectroscopy (AES) and quantified the potassium content in the organic phase. The fraction of receptor $\mathbf{1}$ molecules occupied by a potassium cation after extraction of $2 \mathrm{mM}$ solution of 1 in chloroform with $50 \mathrm{mM} \mathrm{K} \mathrm{SO}_{4}$ aqueous solution was determined to be $36 \%$. After back extraction the potassium content was found to be negligible. This suggests that receptor 1 may act as a suitable candidate as a sulfate transporter. By contrast, neither a binary mixture of a squaramide based anion receptor (denoted as receptor S3 in the ESI $\dagger$ ) with 4-nitrobenzo-18crown-6-ether nor a urea based ion pair receptor (denoted as receptor $\mathrm{S} 4$ in the $\mathrm{ESI} \dagger$ ) is an effective ionophore (see the $\mathrm{ESI} \dagger$ ). Efforts were then made to prove the selectivity of receptor $\mathbf{1}$ towards sulfates and its ability to overcome the Hofmeister bias. Thus we carried out competitive extraction experiments under ion chromatography control. Specifically, an aqueous mixture of $\mathrm{KNO}_{3}$ and $\mathrm{K}_{2} \mathrm{SO}_{4}(5 \mathrm{mM}$ each) was extracted with a $5 \mathrm{mM}$ or $20 \mathrm{mM}$ solution of $\mathbf{1}$ in chloroform, respectively. In both cases a significant decrease in the concentration of sulfates was detected while nitrates were affected only slightly. The drop in concentration was calculated to be 25 and $74 \%$ for sulfates and 4.9 and $7.2 \%$ for nitrates, using 5 and $20 \mathrm{mM} 1$ in chloroform, respectively (Fig. 4). Importantly, the selectivity of receptor 1 towards sulfates was retained even when the spectrum of potassium salts in the aqueous mixture was extended to 


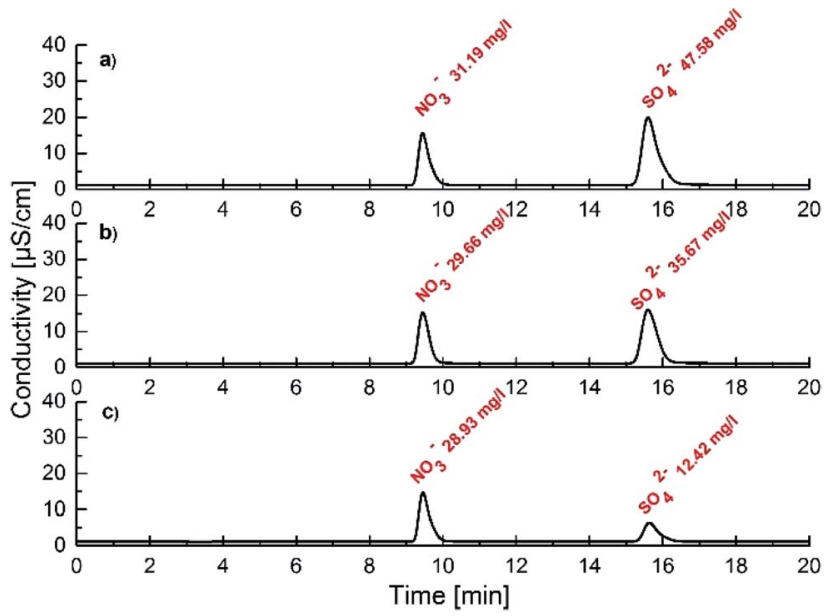

Fig. 4 Chromatograms obtained during extraction experiments after tenfold dilution: (a) source phase, (b) after extraction with $5 \mathrm{mM} 1$ in $\mathrm{CHCl}_{3}$ and (c) after extraction with $20 \mathrm{mM} 1$ in $\mathrm{CHCl}_{3}$.

chlorides, bromides, nitrites and dihydrogen phosphates. On the other hand, the use of a solution containing basic salts such as divalent or trivalent phosphates causes no phase separation most likely due to the deprotonation of the receptor. This indicates the limitations of this system operating at neutral and acidic pH (see the ESI†).

In order to prove the high performance and very high selectivity of receptor 1 towards sulfates we performed more competitive extraction experiments using an aqueous solution containing one order of magnitude higher concentration of potassium nitrate $(50 \mathrm{mM})$ than potassium sulfate. For this reason, the concentration of anions was monitored in the aqueous phase after back extraction. We found that under such conditions receptor $\mathbf{1}$ is still able to preferentially extract extremely hydrophilic sulfates rather than nitrates (Fig. 5). Taking into consideration the assumed stoichiometry of complexes formed with receptor 1 in the organic phase $(1: 1$ for $\mathrm{KNO}_{3}$ and $4: 1$ for $\mathrm{K}_{2} \mathrm{SO}_{4}$ ) the extraction efficiency was calculated to be 6 and $64 \%$ for potassium nitrate and potassium sulfate, respectively. From a practical point of view, this applies to approx. 0.32/0.12 molar ratio of sulfate/nitrate ions in the extract.

Finally, we modified the receptor structure to act as a simple optical sensor (receptor 2) capable of "naked eye" recognition of sulfates. The addition of potassium sulfate to $2.1 \mathrm{mM}$ solution of 2 in DMSO did indeed result in a drastic color change from

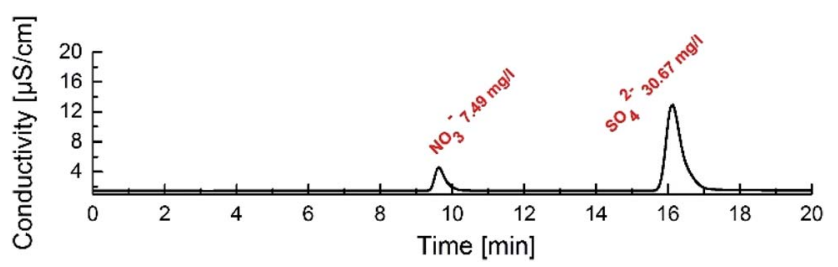

Fig. 5 Chromatogram obtained during back extraction experiments after tenfold dilution. Organic phase: $20 \mathrm{mM}$ receptor 1 in chloroform.
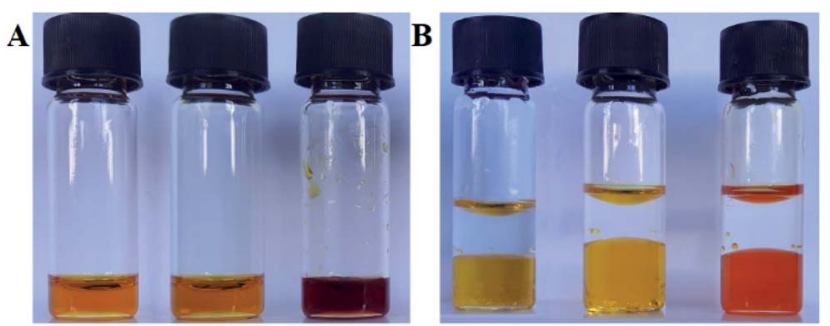

Fig. 6 SLE and LLE experiments. (A) (From left) solution of 2 in DMSO, after addition of solid $\mathrm{KNO}_{3}$, and after addition of solid $\mathrm{K}_{2} \mathrm{SO}_{4}$. (B) (From left) solution of 2 in nitrobenzene and water, solution of 2 in nitrobenzene and aqueous $\mathrm{KNO}_{3}$, and solution of 2 in nitrobenzene and aqueous $\mathrm{K}_{2} \mathrm{SO}_{4}$

orange to purple, while the addition of potassium nitrate did not affect the color change. Similarly, only an aqueous solution of $\mathrm{K}_{2} \mathrm{SO}_{4}$ induced a color change from yellow to red after contacting with $0.5 \mathrm{mM}$ solution of 2 in nitrobenzene (Fig. 6). To gain more insight into the binding ability of receptor 2 and to establish its mechanism of action, we added tetrabutylammonium nitrate and tetrabutylammonium sulfate to the solution of 2 in deuterated DMSO. We found that the nitrate anion does not influence the chemical shifts of signals corresponding to the squaramide protons of receptor 2 . This clearly demonstrates that in such competitive media receptor 2 is not able to form complexes with this anion. On the other hand, the addition of tetrabutylammonium sulfate to the solution of 2 in deuterated DMSO, apart from the color change, resulted in the disappearance of squaramide signals in the ${ }^{1} \mathrm{H}$ NMR spectrum, suggesting deprotonation rather than formation of complexes. This was supported by UV-vis measurements. Particularly, the addition of $\mathrm{TBANO}_{3}$ to the solution of receptor 2 in DMSO does not affect its UV-vis spectrum. Contrarily, upon addition of sulfate anions or basic anions such as acetate or hydroxide, a new bathochromic band in the UV-vis spectra was observed. Based on these findings we concluded that the color change upon addition of sulfates to the solution of 2 originates more likely from the deprotonation event, which is unusual for these anions, making possible the optical differentiation of nitrates and sulfates. This shows its sensing limitations because basic anions also cause a change in the color of the receptor 2 (see the ESI $\dagger$ ). Nevertheless, this system can serve as a facile supportive sensor for monitoring competitive $\mathrm{NO}_{3}{ }^{-} / \mathrm{SO}_{4}{ }^{2-}$ extraction processes using receptor $\mathbf{1}$.

\section{Conclusions}

In summary, a new ion pair receptor was synthesized and characterized by standard spectroscopic methods as well as by DOSY, DLS and single X-ray crystal diffraction analyses. Based on titration experiments we evidenced the high ability of receptor 1 to form complexes with ion pairs. In contrast to potassium salts of the monovalent anions tested, which form $1: 1$ stoichiometry complexes with receptor 1 , in the case of potassium sulfate a $4: 1$ complex was evidenced. This feature was utilized to differentiate the solubility of complexes in 
organic media in favor of the $4: 1$ assembly and enable selective extraction of potassium sulfate from aqueous solution to chloroform. To the best of our knowledge, compound $\mathbf{1}$ is the first ion pair receptor capable of extracting the extremely hydrophilic sulfate anion in the form of an alkali metal salt from the aqueous to the organic phase. We have demonstrated that receptor 1 extracts potassium sulfate selectively even in the presence of lipophilic anions such as nitrates, as shown independently by qualitative ion chromatography analysis. A simple modification of the receptor structure allowed us to obtain a "naked eye" optical sensor 2 capable of detecting sulfates under both SLE and LLE conditions and to do so with selectivity relative to potassium nitrate.

\section{Conflicts of interest}

The authors declare no conflicts of interest.

\section{Acknowledgements}

This work was supported by Grant no. 2018/30/E/ST5/00841 from the National Science Centre, Poland.

\section{Notes and references}

1 (a) I. Ravikumarw and P. Ghosh, Chem. Soc. Rev., 2012, 42, 3077-3098; (b) A. B. Olomu, C. R. Vickers, R. H. Waring, D. Clements, C. Babbs, T. W. Warnes and E. Elias, N. Engl. J. Med., 1988, 318, 1089-1092; (c) A. V. N. Amerongen, J. G. M. Bolscher, E. Bloemena and E. C. I. Veerman, Biol. Chem., 1998, 379, 1-26; (d) S. H. Murch, T. T. MacDonald, J. A. Walker-Smith, M. Levin, P. Lionetti and N. J. Klein, Lancet, 1993, 341, 711-714; (e) K. M. Fritz, S. Fulton, B. R. Johnson, C. D. Barton, J. D. Jack, D. A. Word and R. A. Burke, J. North Am. Benthol. Soc., 2010, 29, 673-689; (f) P. A. Dawson, L. Beck and D. Markovich, Proc. Natl. Acad. Sci. U. S. A., 2003, 100, 13704-13709.

2 Y. Marcus, in Ion Properties, ed. M. Dekker, New York, 1997. 3 (a) R. Custelcean and B. A. Moyer, Eur. J. Inorg. Chem., 2007, 10, 1321-1340; (b) B. A. Moyer and R. P. Singh, in Fundamentals and Applications of Anion Separation, ed. A. B. Bruce and R. P. Raj, Kluwert Academic/Plenum, New York, 2004.

4 (a) B. A. Moyer, R. Custelcean, B. P. Hay, J. L. Sessler, K. Bowman-James, V. W. Day and S. O. Kang, Inorg. Chem., 2013, 52, 3473-3490; (b) E. A. Katayev, A. Ustynyuk and J. L. Sessler, Coord. Chem. Rev., 2006, 250, 3004-3037.

5 (a) C. Jia, B. Wu, S. Li, X. Huang, Q. Zhao, Q. S. Li and X. J. Yang, Angew. Chem., Int. Ed., 2011, 50, 486-490; (b) C. J. Fowler, T. J. Haverlock, B. A. Moyer, J. A. Shriver, D. E. Gross, M. Marquez, J. L. Sessler, M. A. Hossain and K. Bowman-James, J. Am. Chem. Soc., 2008, 130, 1438614387; (c) C. J. Borman, R. Custelcean, B. P. Hay, N. L. Bill, J. L. Sessler and B. A. Moyer, Chem. Commun., 2011, 47, 7611-7613; (d) C. A. Williams, N. J. Seipp, V. S. Bryantsev and B. A. Moyer, Sep. Sci. Technol., 2018, 53, 1864-1873; (e) S. K. Kim, J. Lee, N. J. Williams, V. M. Lynch, B. P. Hay, B. A. Moyer and J. L. Sessler, J. Am. Chem. Soc., 2014, 136, 15079-15085; $(f)$ N. J. Williams, C. A. Seipp,
K. A. Garrabrant, R. Custelcean, E. Holguin, J. K. Keum, J. R. Ellias and B. A. Moyer, Chem. Commun., 2018, 54, 10048-10051; $(g)$ B. Akhuli, I. Ra-vikumar and P. Ghosh, Chem. Sci., 2012, 3, 1522-1530.

6 (a) M. P. Wintererst, T. G. Levitskaia, B. A. Moyer, J. L. Sessler and L. H. Delmau, J. Am. Chem. Soc., 2008, 130, 4129-4139; (b) D. J. White, N. Laing, H. Miller, S. Parsons, P. A. Tasker and S. Coles, Chem. Commun., 1999, 20, 2077-2078; (c) S. K. Kim, V. M. Lynch, N. J. Young, B. P. Hay, C.-H. Lee, J. S. Kim, B. A. Moyer and J. L. Sessler, J. Am. Chem. Soc., 2012, 134, 2087-20843; (d) Q. He, Z. Zhang, J. T. Brewster, V. M. Lynch, S. K. Kim and J. L. Sessler, J. Am. Chem. Soc., 2016, 138, 9779-9782; (e) J. Romański and P. Piątek, J. Org. Chem., 2013, 78, 4341-4347; (f) Q. He, N. J. Williams, J. H. Oh, V. M. Lynch, S. K. Kim, B. A. Moyer and J. L. Sessler, Angew. Chem., Int. Ed., 2018, 57, 1-6; $(g)$ J. M. Mahoney, A. M. Beatty, P. J. Duggan and B. D. Smith, Inorg. Chem., 2004, 43, 5902-5907; (h) D. Jagleniec, S. Siennicka, Ł. Dobrzycki, M. Karbarz and J. Romański, Inorg. Chem., 2018, 57, 12941-12952; (i) Q. He, G. I. VargasZúñiga, S. H. Kim, S. K. Kim and J. L. Sessler, Chem. Rev., 2019, DOI: 10.1021/acs.chemrev.8b00734.

7 J. W. Pflugrath and F. A. Quiocho, Nature, 1985, 314, 257-260. 8 (a) T. Mäkelä, A. Kiesilä, E. Kalenius and K. Rissanen, Chem.Eur. J., 2016, 22, 14264-14272; (b) T. Mäkelä and K. Rissanen, Dalton Trans., 2016, 45, 6481-6490; (c) M. Karbarz and J. Romański, Inorg. Chem., 2016, 55, 3616-3623; (d) T. Mäkelä, E. Kalenius and K. Rissanen, Inorg. Chem., 2015, 54, 9154-9156.

9 (a) R. B. P. Elmes, K. K. Y. Yuen and K. A. Jolliffe, Chem.-Eur. J., 2014, 20, 7373-7380; (b) P. G. Young and K. A. Jolliffe, Org. Biomol. Chem., 2012, 10, 2664-2672; (c) V. J. Dungan, H. T. Ngo, P. G. Young and K. A. Jolliffe, Chem. Commun., 2013, 49, 264-266; (d) P. A. Gale, J. R. Hiscock, C. Z. Jie, M. B. Hursthouse and M. E. Light, Chem. Sci., 2010, 1, 215-220. 10 K. Back and M. Chmielewski, Chem. Commun., 2014, 50, 1305-1308.

11 (a) APEX3, Bruker AXS Inc., Madison, Wisconsin, USA, 2017; (b) SAINT, Bruker AXS Inc., Madison, Wisconsin, USA, 2017; (c) $S A D A B S$, Bruker AXS Inc., Madison, Wisconsin, USA, 2016; (d) TWINABS, Bruker AXS Inc., Madison, Wisconsin, USA, 2012; (e) G. M. Sheldrick, Acta Crystallogr., Sect. A: Found. Adv., 2015, 71, 3-8; (f) G. M. Sheldrick, Acta Crystallogr., Sect. C: Struct. Chem., 2015, 71, 3-8; (g) S. Parsons, H. D. Flack and T. Wagner, Acta Crystallogr., Sect. B: Struct. Sci., Cryst. Eng. Mater., 2013, 69, 249-259; (h) J. M. Cowley, in International Tables for Crystallography, ed. J. C. A. Wilson, Kluwer, Dordrecht, The Netherlands, 1992,vol. C pp. 223-245; (i) C. F. Macrae, I. J. Bruno, J. A. Chisholm, P. R. Edgington, P. McCabe, E. Pidcock, L. Rodriguez-Monge, R. Taylor, J. van de Streek and P. A. Wood, J. Appl. Crystallogr., 2008, 41, 466-470; (j) H. Putz and K. Brandenburg GbR, Diamond - Crystal and Molecular Structure Visualization, Crystal Impact, Kreuzherrenstr, 102, 53227 Bonn, Germany.

12 D. Jagleniec, M. Karbarz, J. Romański, Polish Patent Application No. P.429164, 2019. 